\title{
Microtensile creep testing of freestanding MCrAIY bond coats
}

\author{
Sven Giese ${ }^{1, a)}$, Steffen Neumeier ${ }^{1}$, Doris Amberger-Matschkall ${ }^{1}$, Jan Bergholz ${ }^{2}$, Robert Vaßen ${ }^{2}$, \\ Mathias Göken ${ }^{1, b)}$ \\ ${ }^{1}$ Friedrich-Alexander-Universität Erlangen-Nürnberg (FAU), Materials Science \& Engineering, Institute I, Erlangen 91058, Germany \\ ${ }^{2}$ IEK-1: Materials Synthesis and Processing, Forschungszentrum Jülich GmbH, Institute of Energy and Climate Research, Jülich 52425, Germany

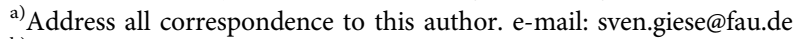 \\ b) This author was an editor of this journal during the review and decision stage. For the JMR policy on review and publication of manuscripts authored \\ by editors, please refer to http://www.mrs.org/editor-manuscripts/. \\ Received: 25 February 2019; accepted: 23 April 2019
}

Bond coats are essential in gas turbine technology for oxidation protection. Freestanding MCrAIY ( $M=N i$, Co) bond coats were investigated with respect to their creep strength at elevated temperatures. Three types of MCrAlY, a Ni-based bond coat Amdry 386, a Co-based bond coat Amdry 9954 and Amdry $9954+2$ wt $\% \mathrm{Al}_{2} \mathrm{O}_{3}$ (ODS = oxide dispersion strengthened) produced by low pressure plasma spraying, were analyzed. The two phase microstructure of the bond coats consists of a fcc $\gamma$-Ni solid solution and a B2 $\beta$-NiAl phase. Constant load experiments were performed in a thermomechanical analyzer at temperatures between 900 and $950{ }^{\circ} \mathrm{C}$. Microtensile test specimens with a diameter of $450 \mu \mathrm{m}$ were produced by a high-precision grinding and polishing process. Creep rupture was mainly due to void nucleation along the $\beta-\gamma$ interfaces and grain boundaries. The time to failure is larger in Ni-based Amdry 386 compared to that in Co-based Amdry 9954 due to a higher fraction of the high-strength $\beta$-NiAl phase at test temperatures. The addition of ODS-particles in the Co-based bond coat Amdry 9954 resulted in a better creep resistance but lower ductility in comparison to ODSparticle-free Amdry 9954.

\section{Introduction}

The continuous improvement of aero engines and land-based gas turbines leads to increasing gas inlet temperatures and the demands for new materials. Such increased temperatures are possible with thermal barrier coating (TBC) systems consisting of $\mathrm{Al}$ - and $\mathrm{Cr}$-containing bond coatings for enhanced oxidation- and corrosion resistance and ceramic TBCs, which are essential for thermal isolation [1]. The difference in thermal expansion coefficients between the metal substrate and the TBC would lead to delamination. A metallic bond coat can improve the bonding between substrate and TBC and can reduce the risk of spallation of the ceramic top coat. Therefore, MCrAlY overlay coatings are applied to superalloy components, tailored to provide protection against high-temperature oxidation and hot corrosion [2, 3, 4, 5, 6, 7]. Studies have investigated hardness, Young's modulus, diffusion or the influence of bond coats with different chemical compositions on the mechanical properties of the superalloys so far $[8,9,10$,
11]. However, less information about the mechanical properties of bond coats themselves exists [12]. This is certainly disadvantageous, as the mechanical properties of the bond coats determine, to a certain extent, the relaxation and the local stress state, especially on rough bond coats within in the system [13]. With respect to the importance of relaxation at high temperatures, creep-resistant bond coats (e.g., by the addition of oxide phases) might be beneficial. In addition, it was also observed that ODS bond coats show a superior oxidation and thermal cyclic performance $[14,15]$. It is known that ODS-NiAl shows a remarkable creep resistance at temperatures up to $1000{ }^{\circ} \mathrm{C}$. The creep behavior of fine-grained ODS-NiAl is described by Arzt et al. for materials with undissociated dislocations, like in $\mathrm{NiAl}$ (Göhring-Arzt model) [16]. A complex creep behavior as a mixture of diffusional and detachment controlled creep mechanisms was observed $[16,17,18,19]$. TEM investigations on ODS-NiAl, $-\mathrm{FeAl}$ and $-\mathrm{Ni}_{3} \mathrm{Al}$ reveal that the size of the ODS particles has a large influence on the interaction between the 
particle and the dislocations. If the particle is twice as large as the dissociation width of the dislocation, the leading particle is strongly attached to the ODS particle and this force must be overcome before the dislocation can fully detach [20]. The mechanical properties of bond coats and the influence of ODSparticles on the creep behavior of freestanding bond coats are analyzed. For this, microtensile samples are used with a diameter of a few hundred micrometers. The thickness of the tested samples is in the range of the coating thickness and therefore allows testing of the bond coats independent of any substrate influence. Studies of microtensile testing of small samples under uniaxial loading are a reliable technique to evaluate the mechanical properties at the microscale $[8,21,22$, 23]. As known from the literature, the mechanical properties obtained by microtensile tests agree well with macroscopic tests [24]. Dog-bone-shaped miniaturized specimens made from Nimonic-75 samples verified by Luan and Riesch-Oppermann show that the minimum creep rates of the miniaturized specimens are in agreement with the steady-state creep strain rates of conventional specimens [24]. However, microtensile creep experiments of freestanding bond coat have not been investigated in detail so far. Alam et al. developed a hightemperature tensile device for micromechanical characterization of metallic alloys and ceramic coatings [21]. With this device, creep experiments on small flat tensile specimens of $\mathrm{Ni}$ base superalloys Ni-625 and René 88DT were performed [21]. Kumar et al. investigated the influence of reducing the sample thickness of miniaturized samples on the mechanical properties compared to macroscopic tensile tests [25]. Tensile tests and FEM simulations showed good agreement relating to yield stress, ultimate tensile strength and uniform elongation for three steel alloys down to a thickness of $0.25 \mathrm{~mm}$. However, due to the smaller sample volumes, the strain to failure decreased with thinner sample thickness due to earlier necking and micro-void coalescence [25, 26]. A sample processing procedure for cylindrical submillimeter tensile specimens with a homogeneous thickness over the whole gauge length, similar to those used in this work, was described by Rathmayr et al. [27]. By using circular cross sections of the tested samples, stress concentrations due to the geometric shape are avoided and surface inhomogenities are minimized during polishing. Nevertheless, achieving a homogeneous sample thickness and prevention of plastic deformation during sample preparation are quite challenging. A precise temperature and load control during testing is required. Therefore, the creep experiments on the microtensile samples were conducted in a thermomechanical analyzer (TMA) with excellent temperature control. The aim of the work was to demonstrate that the TMA setup using microtensile creep specimens provides a suitable method for determining the mechanical properties of freestanding MCrAlY bond coats with different $\mathrm{Ni}$ and Co contents at their operating temperature and thickness. The different creep behavior of $\mathrm{Ni}$ and Co-based bond coats depending on their chemical composition as well as the influence of the strengthening effect of ODS-particles is discussed to design improved bond coats for future applications.

\section{Results}

\section{Microstructure of the initial state}

The two-phase microstructure of Amdry 386 and 9954, after the first annealing step of $2 \mathrm{~h}$ at $1100{ }^{\circ} \mathrm{C}$, consists of $\beta$-NiAl (dark), $\gamma-\mathrm{Ni} / \mathrm{Co}$-solid solution (bright), and an additional third phase $\left(\mathrm{Al}_{2} \mathrm{O}_{3}\right)$ in the case of the $9954+$ ODS coating, as shown in Fig. 1.

Due to its higher content of $\mathrm{Ni}$ and $\mathrm{Al}$, Amdry 386 shows a higher fraction of the $\beta$-NiAl phase with $60 \pm 0.5 \%$ compared to Amdry 9954 with $31 \pm 1.2 \%$, see Fig. 2(a). The addition of $2 \mathrm{wt} \%$ of $\mathrm{Al}_{2} \mathrm{O}_{3}$ particles does not have a significant influence on the phase fractions. The distribution of the ODSparticles is even and larger accumulations could rarely be observed, see Fig. 1(f). The additional heat treatment of $72 \mathrm{~h}$ at $1100{ }^{\circ} \mathrm{C}$ does not have a significant influence on the area and the phase fractions of all bond coats, Figs. 2(a) and 2(b).

Furthermore, the grain sizes after the first $(2 \mathrm{~h})$ and the second heat treatment $(72 \mathrm{~h})$ were analyzed, Fig. 2(c). For Amdry 386 and especially for the ODS-containing bond coat, the grain size distribution is broader after a thermal exposure of $2 \mathrm{~h}$ compared to the additional second heat treatment of $72 \mathrm{~h}$. After the second heat treatment, all three bond coats show a more homogeneous grain size distribution, resulting in a smaller standard deviation. After the first heat treatment, some unmelted particles, marked with a black dashed line, due to the coating process are still visible, Fig. 2(d). After the second heat treatment, the amount of these unmelted particles is reduced, narrowing the grain size distribution. Furthermore, the coarsening of the smaller grains led to a more homogeneous distribution after the additional heat treatment of $72 \mathrm{~h}$. A few unmelted particles were still observed and were often surrounded by a semicontinuous $\beta$-phase layer acting as preferred regions for cracking [28]. Chen et al. investigated the influence of these unmelted particles on the mechanical properties with a similar bond coat Amdry 9951 in compression tests and determined a coarsening rate coefficient for the $\beta$-phase up to $1100{ }^{\circ} \mathrm{C}$ of $6.49 \times 10^{-5} \mu^{3} / \mathrm{s}[28,29]$.

\section{Microtensile creep experiments}

Microtensile creep curves were measured for Amdry 386, 9954, and 9954 + ODS at temperatures between 900 and $950{ }^{\circ} \mathrm{C}$, Fig. 3. The Ni-based bond coat Amdry 386 shows a higher creep strength than the Co-based bond coat Amdry 9954 at all 

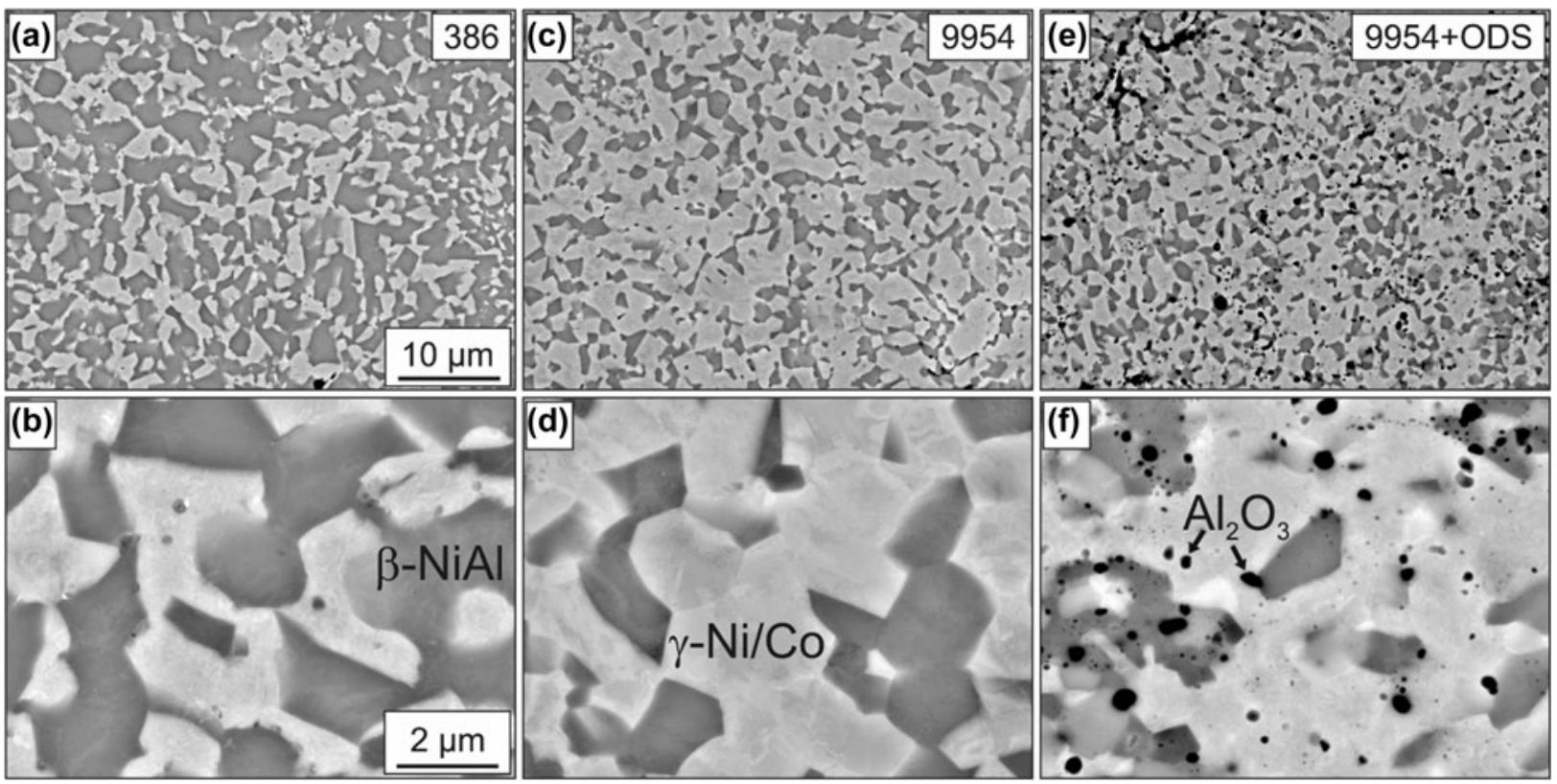

Figure 1: BSE images of the microstructures of Amdry $386(a+b)$, Amdry $9954(c+d)$ and Amdry $9954+$ ODS $(e+f)$ after a heat treatment of $2 \mathrm{~h}$ in vacuum at $1100{ }^{\circ} \mathrm{C}$.
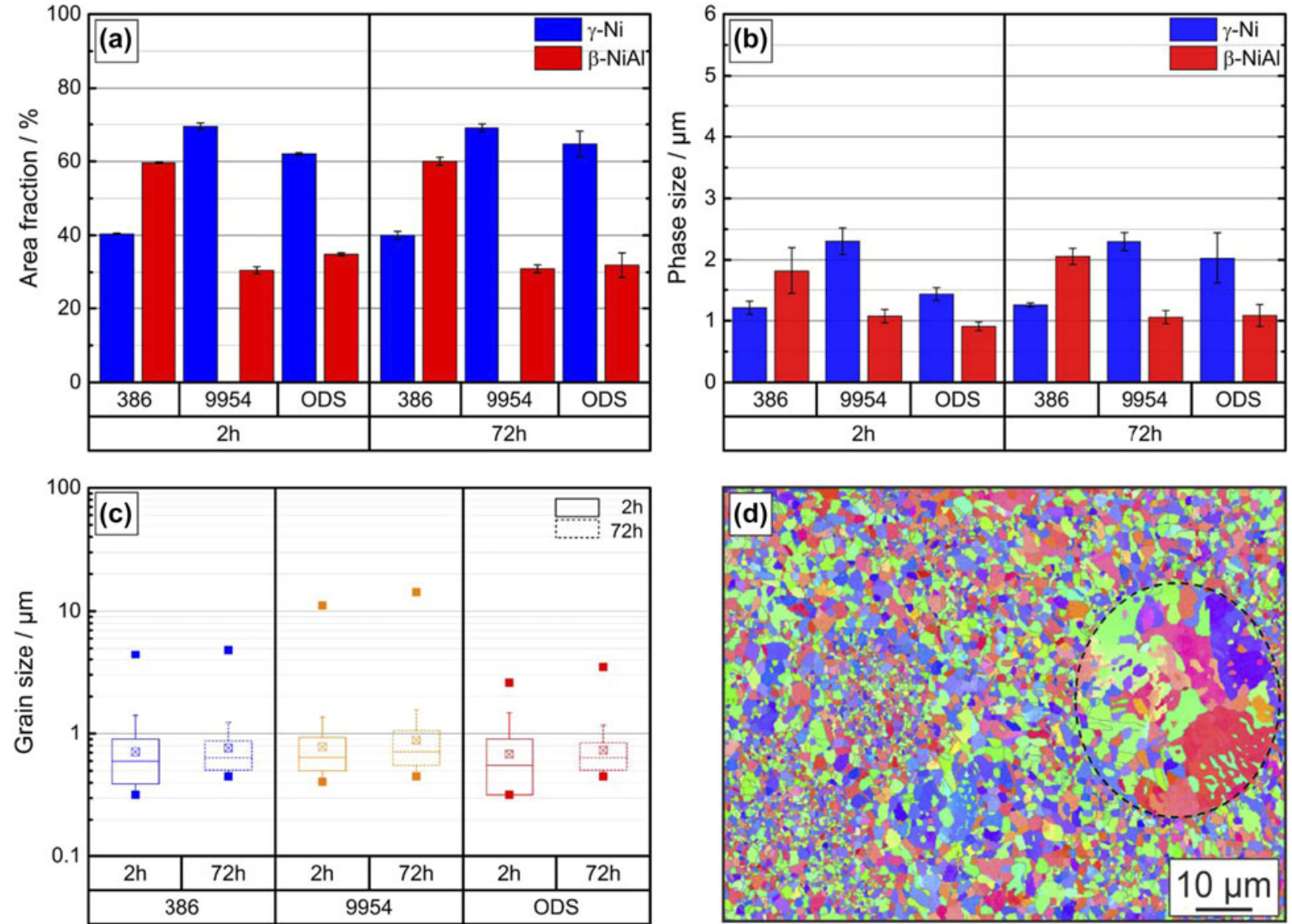

Figure 2: (a) Area fraction of phases and (b) phase size (c) grain sizes of Amdry 386, Amdry 9954 and Amdry $9954+$ ODS after a heat treatment of 2 and $72 \mathrm{~h}$ at $1100{ }^{\circ} \mathrm{C}$ in vacuum before testing and (d) an EBSD mapping of Amdry 9954 with a large unmelted particle due to insufficient homogenization during thermal exposure. 

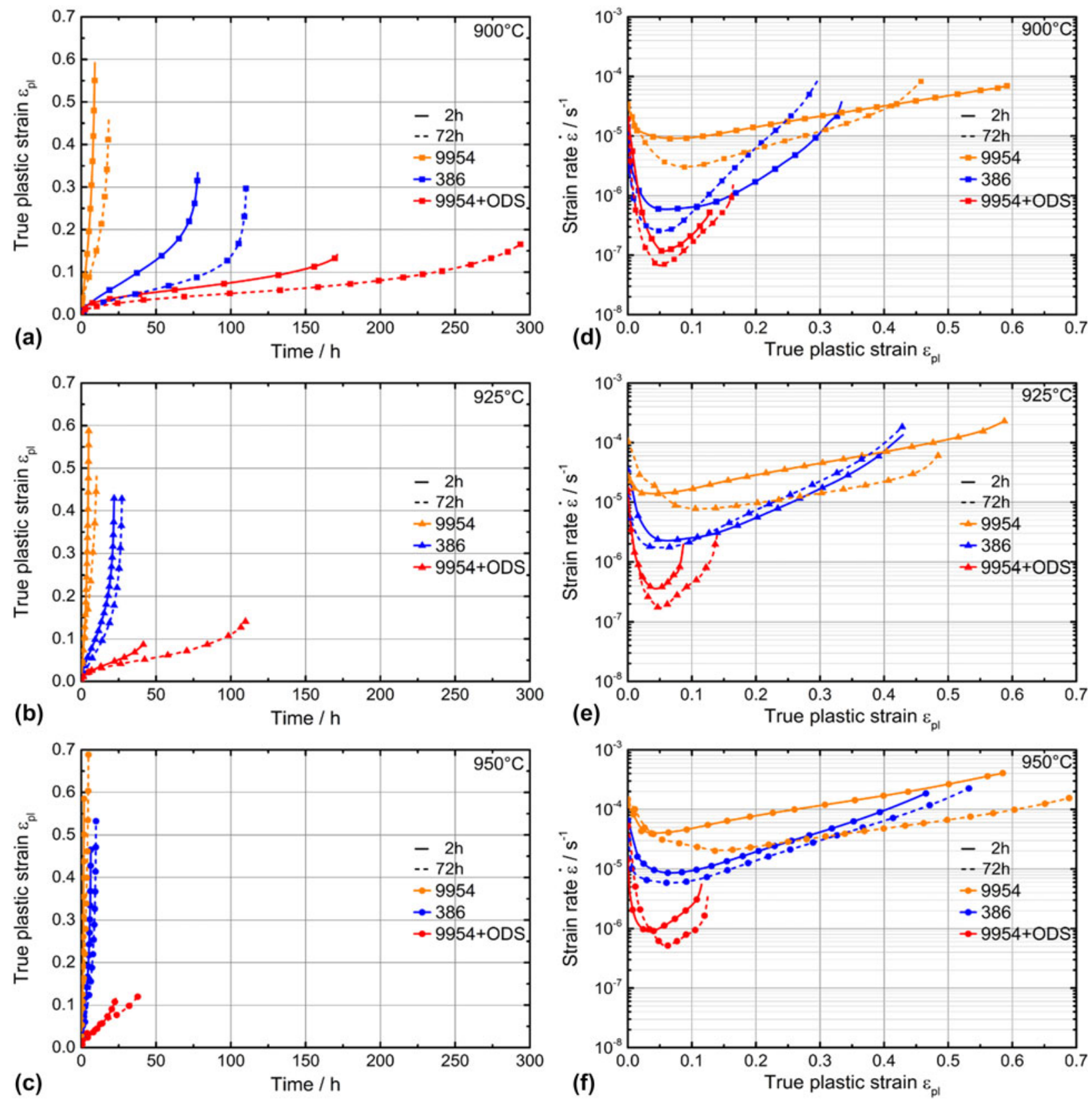

Figure 3: True plastic strain over time plot (a-c) and strain rate over true plastic strain plot (d-f) of Amdry 386, Amdry 9954 and Amdry $9954+$ ODS after aging at $1100{ }^{\circ} \mathrm{C}$ for $2 \mathrm{~h}$ (solid lines) and $72 \mathrm{~h}$ (dashed lines) at testing temperatures of $900-950{ }^{\circ} \mathrm{C}$ with $15 \mathrm{MPa}$.

temperatures, due to the higher amount of $\beta-\mathrm{NiAl}$ in Amdry 386 compared to Amdry 9954. However, Amdry 9954 with $\mathrm{Al}_{2} \mathrm{O}_{3}$-particles reveals the highest creep resistance because the addition of $\mathrm{Al}_{2} \mathrm{O}_{3}$-particles to Amdry 9954 outweighs the lower $\beta$-NiAl content. The creep minima occurred at all temperatures at a plastic strain of about $0.05-0.1$. The slope of the creep curves after the creep minima increases, whereas the strain to failure of the ODS-free bond coats increases with increasing temperature. The long-term heat-treated conditions $\left(1100{ }^{\circ} \mathrm{C} /\right.$ $72 \mathrm{~h}$ ) of all bond coats showed a higher creep strength than the short-term heat-treated conditions $\left(1100{ }^{\circ} \mathrm{C} / 2 \mathrm{~h}\right)$. A comparison of the creep minima of the three bond coats at all testing temperatures is shown in Fig. 4(a).

The differences of the creep minima after different durations of thermal exposure are more pronounced for Amdry 386 compared to Amdry 9954. The lower amount of $\beta$-NiAl led to smaller differences for the Co-based bond coat. The equal creep minima for Amdry 386 tested at $950{ }^{\circ} \mathrm{C}$ and Amdry 9954 tested at $900{ }^{\circ} \mathrm{C}$ are quite similar, which shows the significant influence of the composition and the content of phases in the 

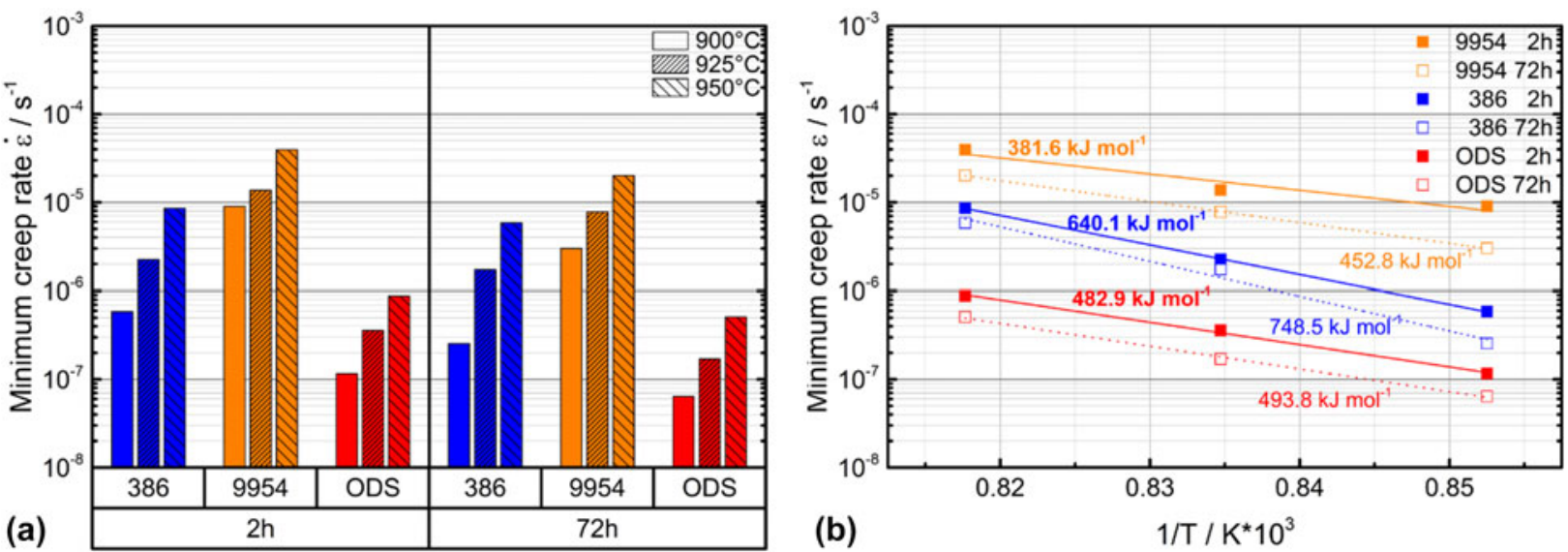

Figure 4: (a) Minima creep rates of Amdry 386, Amdry 9954 and Amdry $9954+$ ODS at testing temperatures of $900-950{ }^{\circ} \mathrm{C}$ and an applied stress of 15 MPa after a first $(2 \mathrm{~h})$ and an additional second $(72 \mathrm{~h})$ heat treatment and (b) activation energies of all three bond coats at all testing temperatures.

bond coats. The activation energy of creep for the three bond coats determined by tensile tests between 900 and $950{ }^{\circ} \mathrm{C}$ after short- and long-term heat treatment reveals that the activation energy after the additional heat treatment is higher than for the experiments after the short-term heat treatment, Fig. 4(b).

$$
Q=-2.304 \times R \times \frac{d(\lg \dot{\varepsilon})}{d\left(\frac{1}{T}\right)},
$$

$Q$ is the activation energy, which can be calculated as the slope of the minimum creep rate against the inverse temperature and the gas constant $R$. Amdry 386 shows the highest activation energy followed by Amdry 9954 + ODS. Amdry 9954 showed the strongest creep deformation at all testing temperatures, which corresponds to the low activation energy of creep.

\section{Microstructure after creep experiments}

The microstructure of the tensile specimens of all three bond coats after $72 \mathrm{~h}$ of thermal exposure and creep testing at $950{ }^{\circ} \mathrm{C}$ at a constant force of $2.35 \mathrm{~N}$ until fracture can be seen in Fig. 5. Due to the large plastic deformation, Amdry 386 and especially Amdry 9954 show very ductile fracture behavior. In contrast to 9954, the oxide dispersion strengthened bond coat 9954 + ODS failed more brittle at an earlier state according to a larger diameter of the fracture surface, based on the higher strength and lower ductility of the alloy. Cracks could be observed at phase and grain boundaries between $\beta$-NiAl and $\gamma$-solid solution inside the samples as well as starting at the surface of the bond coats. The ODS-particles are equally distributed in the $\beta$-NiAl phase and the $\gamma$-solid solution for Amdry 9954 + ODS.

The grain size of all bond coats was analyzed by EBSD after heat treatment of $72 \mathrm{~h}$ at $1100{ }^{\circ} \mathrm{C}$ and after the same heat treatment and microtensile tests at $950{ }^{\circ} \mathrm{C}$, Fig. 6(a). All bond coats show an increase in their grain size after tensile testing. This increase occurred due to normal grain coarsening during the creep test. The ODS bond coat showed smaller grain sizes before and after tensile tests compared to the ODS-free coatings but did not prevent grain coarsening. In addition to the grain size, Fig. 6(b) shows the size of the $\gamma-\mathrm{Ni}$ phase and $\beta$-NiAl phase for all bond coats after the creep experiments at $950^{\circ} \mathrm{C}$ after the short-term $\left(1100^{\circ} \mathrm{C} / 2 \mathrm{~h}\right)$ and the long-term $\left(1100{ }^{\circ} \mathrm{C} / 72 \mathrm{~h}\right)$ heat treatment. The additional long-term heat treatment leads to a much stronger increase of the phase sizes of all three bond coats compared to the initial state, see Fig. 2(b). It is also noticeable that the addition of ODS-particles does not lead to a significant prevention of phase coarsening.

To investigate the arrangement of the grains depending on their size before and after microtensile tests, grain sizes smaller than the median grain sizes of Amdry 386 and Amdry 9954 + ODS were pigmented in red, Fig. 7 . Therefore, the microstructures of these samples were analyzed along the loading axis by EBSD measurements. After the additional heat treatment of $72 \mathrm{~h}$ and before the creep experiment, the median grain size was $0.6 \mu \mathrm{m}$ for Amdry 386 and $0.45 \mu \mathrm{m}$ for the ODS-containing bond coat and grains smaller than the median were found all over the specimen. Accumulation of areas with smaller grains, especially for Amdry 386, could be observed. Figure 7(b) shows the coarsening of the grains due to the time and temperature during the creep test. The median grain size after the creep tests was about $1.55 \mu \mathrm{m}$ for Amdry 386 and $0.8 \mu \mathrm{m}$ for the ODS-containing bond coat. It can clearly be seen that for Amdry 386, the smaller grains are mainly elongated along the loading axis, separated by layers of larger grains. In contrast to that, no preferential 

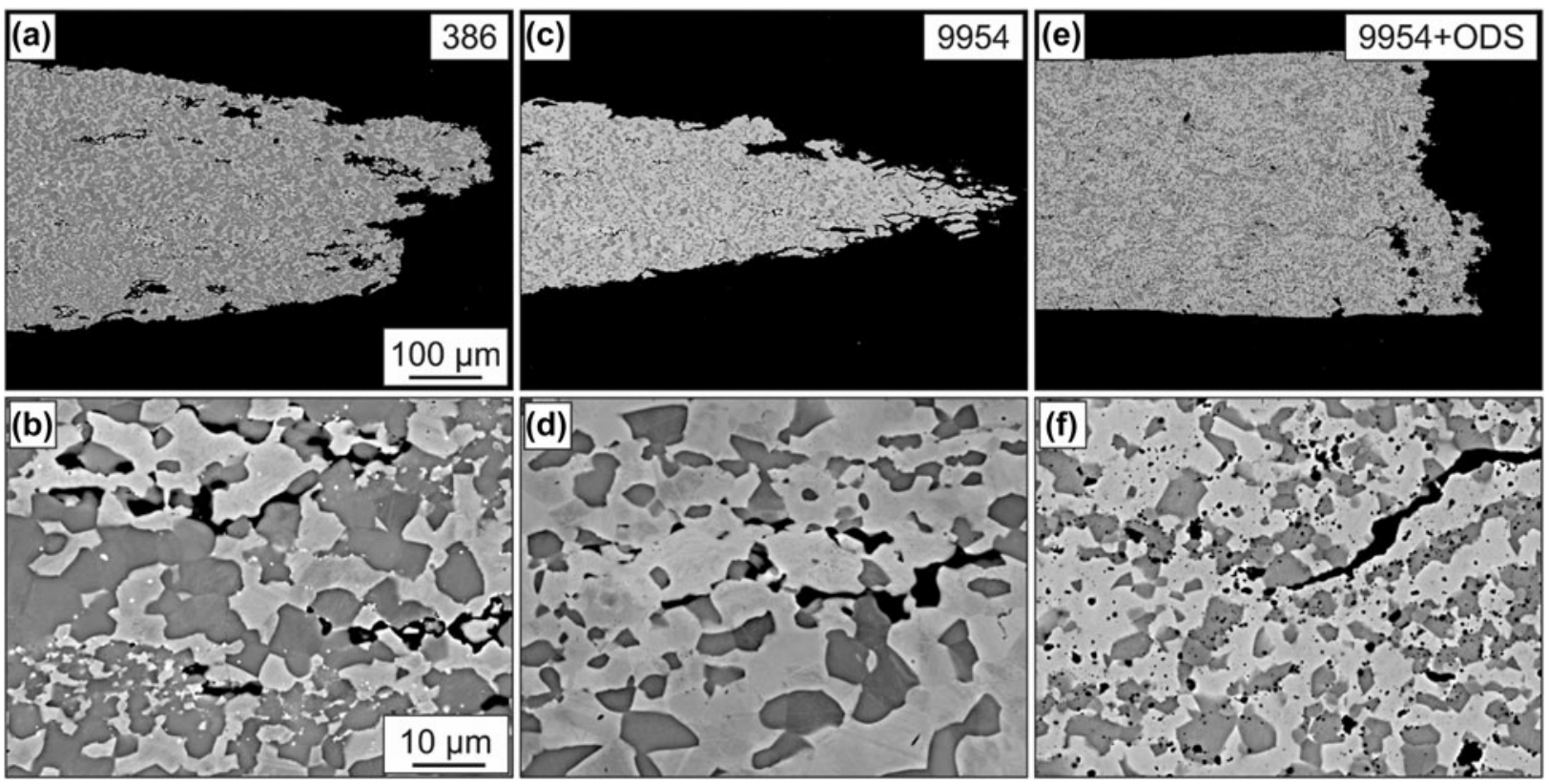

Figure 5: BSE images of the microstructures of Amdry $386(a+b), 9954(c+d)$ and $9954+$ ODS $(e+f)$ after $72 \mathrm{~h}$ of thermal exposure and microtensile creep tests at $950{ }^{\circ} \mathrm{C}$.
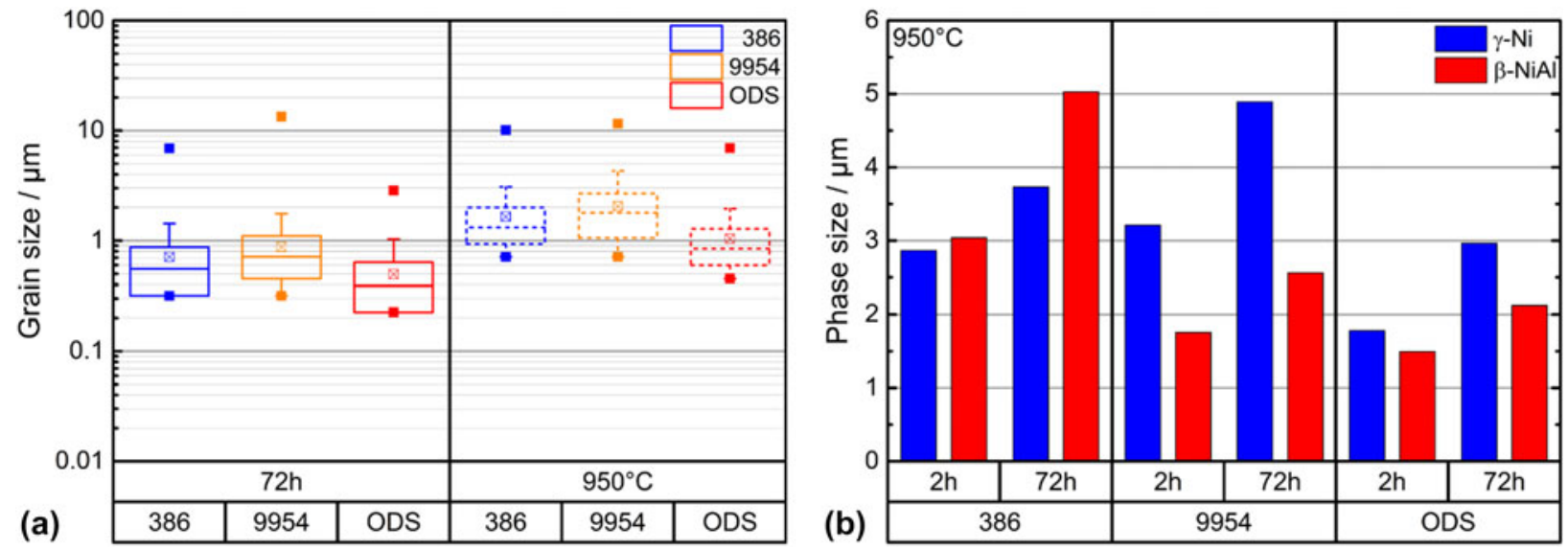

Figure 6: Grain sizes of Amdry 386, Amdry 9954 and Amdry 9954 + ODS (a) after $72 \mathrm{~h}$ of thermal exposure and after the same heat treatment and microtensile tests at $950{ }^{\circ} \mathrm{C}$ and (b) phase sizes after microtensile creep tests at $950{ }^{\circ} \mathrm{C}$ heat treated for 2 and $72 \mathrm{~h}$ at $1100{ }^{\circ} \mathrm{C}$ in vacuum.

accumulation of smaller grains could be observed for the ODS-containing bond coat, Fig. 7(d).

\section{Discussion}

In this work, microtensile tests on three different MCrAlY-bond coats after heat treatments of 2 and $72 \mathrm{~h}$ at $1100{ }^{\circ} \mathrm{C}$ were performed in the temperature range between 900 and $950{ }^{\circ} \mathrm{C}$. The second heat treatment led to grain coarsening, resulting in lower creep rate minima during all experiments. The higher $\beta$-NiAl amount of Amdry 386 is responsible for the superior creep properties in comparison to Amdry 9954, which contains less $\beta$-NiAl and therefore more $\gamma$-solid-solution phase. This is due to the higher creep strength of $\mathrm{NiAl}$, as compared to $\mathrm{Ni}$ at temperatures above $900{ }^{\circ} \mathrm{C}$, which was investigated in previous studies [30, 31, 32, 33]. Moreover, the higher yttrium content in Amdry 386 leads to a higher amount of small $\mathrm{Y}_{2} \mathrm{O}_{3}$-particles during plasma spraying. These nanoscale oxides resulted in an additional hindering effect for deformation. After the tensile creep experiments, an increase of the size of the $\gamma$-solid-solution phase, $\beta$-NiAl phase and the ODS-particles was observed. The grain size of all tested conditions increased slightly. However, an inhomogeneous grain coarsening of the grains took place in the 

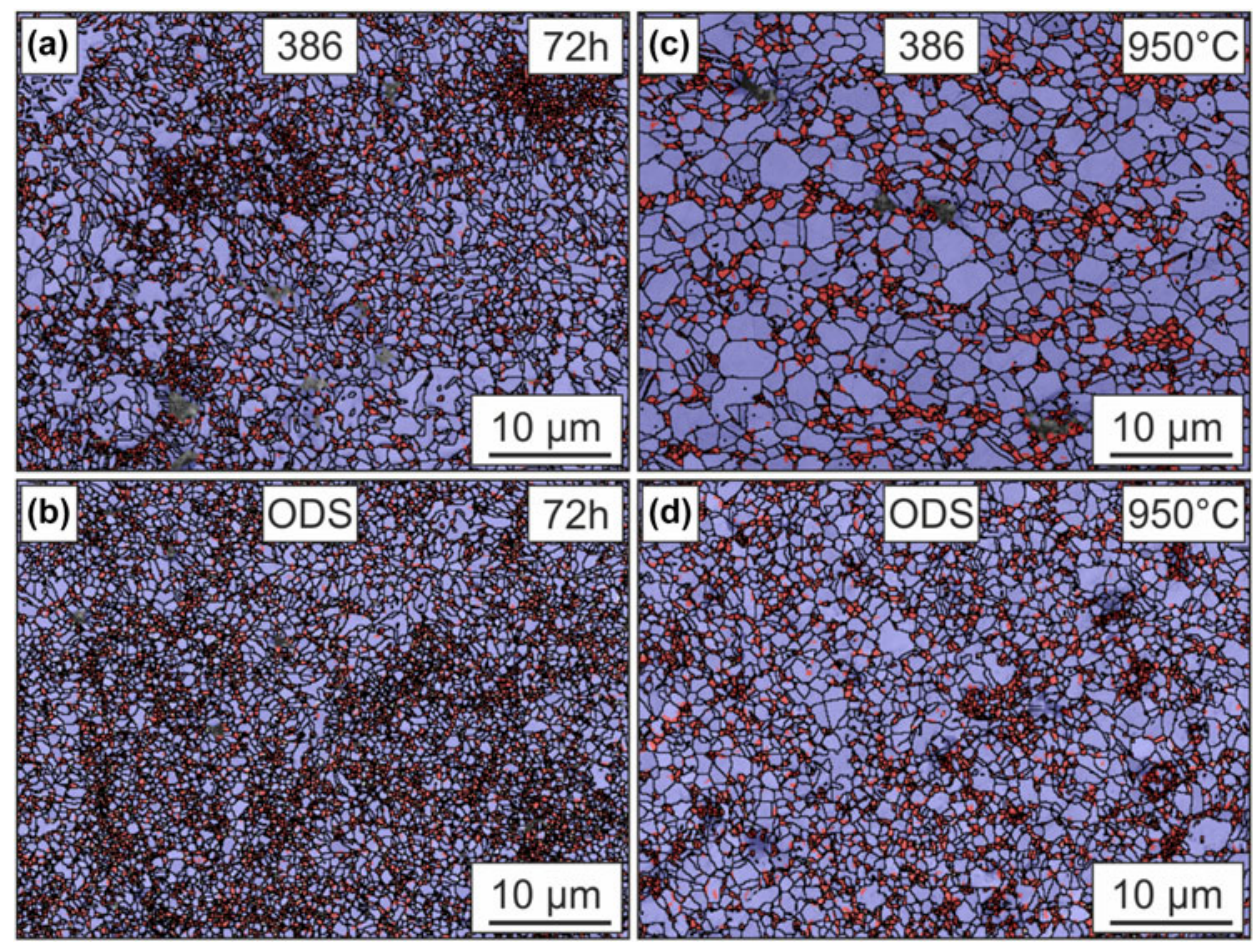

Figure 7: EBSD measurements after thermal exposure of $72 \mathrm{~h}$ of (a) Amdry 386 and (b) Amdry $9954+$ ODS. EBSD measurements after the same heat treatment and microtensile tests at $950^{\circ} \mathrm{C}$ for (c) Amdry 386 and (d) Amdry $9954+$ ODS. Grains smaller than the median grain sizes (red) and grains larger than the medium grain size (purple).

ODS-free bond coat. After testing, EBSD measurements revealed layers of grains smaller and larger than the median grain size which were aligned along the loading axis of Amdry 386 and Amdry 9954. This alternately layered structure occurred presumably due to the formation of small oxides during the manufacturing process. The deformation mechanism in this stress temperature regime should be grain boundary sliding, as described in former studies by Hebsur [34]. However, due to the high activation energies of the bond coats, determined at this work, dislocation creep is suggested to be the dominant deformation mechanism.

The superior creep resistance of Amdry 9954 + ODS in comparison to the dispersoid-free Amdry 9954 can be explained by the detailed investigations of Arzt et al. on the addition of 2 at.\% of yttria particles in $\mathrm{NiAl}$ with similar fine grain size compared to our bond coats [16, 17]. It is assumed that the nanoscaled oxides $\mathrm{Al}_{2} \mathrm{O}_{3}$ particles provide a similar beneficial effect of dispersion strengthening and hinder the dislocation motion. This results in a higher activation energy, but also leads to a much lower plastic strain to failure.

\section{Conclusion}

Small-scale tensile creep experiments have been performed on three freestanding MCrAlY bond coats using a TMA. To investigate the mechanical properties of the bond coats independent of the substrate, small cylindrical tensile specimens with a precise and reproducible shape were fabricated by grinding and polishing to a diameter of $450 \mu \mathrm{m}$. Forcecontrolled creep experiments were performed at temperatures between 900 and $950{ }^{\circ} \mathrm{C}$ under constant Ar-flow at a constant load of $2.35 \mathrm{~N}$. The higher amount of $\beta$-NiAl in the Ni-based bond coat Amdry 386 led to superior creep properties in comparison to the Co-based bond coat Amdry 9954. A longer annealing heat treatment of $72 \mathrm{~h}$ compared to $2 \mathrm{~h}$ at $1100{ }^{\circ} \mathrm{C}$ led to lower creep rates for all three bond coats at all testing temperatures due to grain coarsening of both phases. The main deformation mechanism for Amdry 386 and Amdry 9954 could be determined as dislocation creep. The addition of ODS particles in Amdry 9954 led to a significant decrease of the creep rate due to the additional interaction between the dislocation and the oxide particles. The strain to failure decreases from around 0.6 for Amdry 9954 to 0.14 for Amdry $9954+$ ODS.

\section{Methodology}

\section{Material}

Three MCrAlY bond coats were investigated in this study. An Nibased NiCoCrAlY (Amdry 386) and two Co-based CoNiCrAlY (Amdry 9954) bond coats. One of the Co-based bond coats 
TABLE I: Composition of Amdry 386 and Amdry 9954 (+ODS) in at.\%.

\begin{tabular}{lccccccc}
\hline \hline At.\% & $\mathrm{Ni}$ & $\mathrm{Co}$ & $\mathrm{Al}$ & $\mathrm{Cr}$ & $\mathrm{Si}$ & $\mathrm{Y}$ & $\mathrm{Hf}$ \\
\hline Amdry 386 & 40.35 & 18.97 & 23.04 & 16.49 & 0.79 & 0.36 & 0.08 \\
Amdry 9954 & 28.68 & 34.18 & 15.57 & 21.25 & 0.13 & 0.32 & $\ldots$ \\
Amdry 9954 + ODS & 29.59 & 35.01 & 16.52 & 18.64 & 0.08 & 0.16 & $\ldots$ \\
\hline
\end{tabular}

contains additional $2 \mathrm{wt} \%$ of $\mathrm{Al}_{2} \mathrm{O}_{3}$ for oxide dispersion strengthening (ODS) (Amdry $9954+$ ODS) produced by mechanical alloying [36]. The chemical compositions are listed in Table I.

Coatings with a thickness of approximately $3 \mathrm{~mm}$ were produced by low-pressure plasma spraying using a $\mathrm{F} 4$ torch in an Oerlikon Metco (Wohlen, Switzerland) facility on a steel substrate. Afterwards, plates of $20 \times 10 \times 2 \mathrm{~mm}$ in size were spark eroded out of the coating layer and heat treated in argon atmosphere at $1100{ }^{\circ} \mathrm{C}$ for $2 \mathrm{~h}$. Then, half of the samples got an additional heat treatment for $72 \mathrm{~h}$ under equal conditions to investigate the influence of thermal exposure. The porosity of the samples in the as-sprayed conditions was about $0.55 \pm$ $0.14 \%$ and decreases after the first heat treatment of $2 \mathrm{~h}$ at $1100{ }^{\circ} \mathrm{C}$ to $0.2 \pm 0.08 \%$. No significant change of the porosity was to be observed after the additional heat treatment.

\section{Sample preparation}

The specimens were cut with a precision wet abrasive cutting machine Brillant 220 from ATM to a width of about $550 \mu \mathrm{m}$. For the preparation of a small circular microtensile specimen out of the rectangular shape, a further step was necessary. The challenge of producing microtensile specimens, especially of dimensions below $1 \mathrm{~mm}$, is that notches across the gauge length and an inhomogeneous sample thickness can have a much larger influence on the experimental results, as with standard tensile specimens on the macroscale. This means that the cross section, no matter if it is rectangular or circular, must be well known and reproducible for all samples. Common fabrication techniques for rectangular tensile specimens are mechanical milling or electrical discharge machining methods $[37,38]$. Samples with rectangular cross sections are commonly used for macroscopic testing. In the submillimeter range, the sample edges of rectangular-shaped samples are rounded. This results in inaccurate determinations of the cross section and edges that are preferential sites for notches because of insufficient grinding and polishing. To eliminate the influence of varying geometries and to prove the reliability and reproducibly of the tensile tests on the submillimeter scale, the use of samples with circular cross sections is more suitable. To produce specimens with circular cross sections without notches and high accuracy, the sliced samples were prepared by a highprecision grinding and polishing process at Microsample $\mathrm{GmbH}$, specialized to produce circular samples with diameters smaller than $1 \mathrm{~mm}$. The specimen is fixed in a specimen holder with two grips. A liquid cooling system prevents any heat influence during milling with a diamond wire wheel. The desired gauge length can be adjusted before tailoring the sample. During grinding, the sample holder rotates synchronic to prevent any torsion effect in the sample and is mounted perpendicular to the rotation axis of the grinding wheel. The measurement of the sample diameter is monitored at high speed and high precision with a 2D optical micrometer system. After grinding, further polishing steps are performed to smoothen the sample surface, removing the thin mechanically affected zone of the grinding process and reducing notches [27, 39]. The cross section was determined to be $450 \pm 2 \mu \mathrm{m}$ in diameter, over the entire gauge length of $2500 \mu \mathrm{m}$. The surface roughness of $2 \mu \mathrm{m}$ was determined by a VHX-1000-laser microscope from Keyence, Osaka, Japan.

Microstructural analysis before and after testing was carried out with a Zeiss Crossbeam 540 (Oberkochen, Germany) using back-scattered electron imaging (BSE). The area fraction, as well as the phase and grain size of the individual phases, was determined by electron backscatter diffraction (EBSD) with the software ATZEC from Oxford Instruments, Abingdon, U.K. Longitudinally polished sections of the tested specimens after the tensile creep experiments were analyzed by the software ImageJ in horizontal direction $250 \mu \mathrm{m}$ away from the crack tip.

\section{TMA}

The microtensile creep tests were performed in a SiC furnace of a thermomechanical analyzer type 402 F3 Hyperion from Netzsch, Selb, Germany. The advantage of this setup is a very accurate, controllable force and length resolution during the creep tests. The force sensor has a digital resolution smaller than $0.01 \mathrm{mN}$ and a force range from $1 \mathrm{mN}$ to a maximum of 3 $\mathrm{N}$. Therefore, testing of small samples or thin coatings in the conditions, which are commonly used during service, can be investigated. The change in length of the sample is measured accurately by an inductive linear variable displacement transducer (LVDT) with a digital resolution of $1.25 \mathrm{~nm}$ and a maximum change in length of $4 \mathrm{~mm}$. During the tests, the measuring system is thermally stabilized by water cooling. Hebsur et al. studied NiCoCrAlY bond coats, which were tested in vacuum and air between 660 and $850{ }^{\circ} \mathrm{C}$ [8]. The negative effect of oxygen on NiCoCrAlY bond coats led to blunting of initial surface pores during testing. Hence, in this work, a constant argon gas flow was applied to prevent oxidation of the samples. Creep tests were performed at 900, 925, and $950{ }^{\circ} \mathrm{C}$ under a constant argon flow of about $200 \mathrm{~mL} / \mathrm{min}$. Before testing, the samples were heated up with $5 \mathrm{~K} / \mathrm{min}$ under a constant load of $50 \mathrm{mN}$ to fix the specimen until the testing temperature is achieved. A holding period of $2 \mathrm{~h}$ was used to 

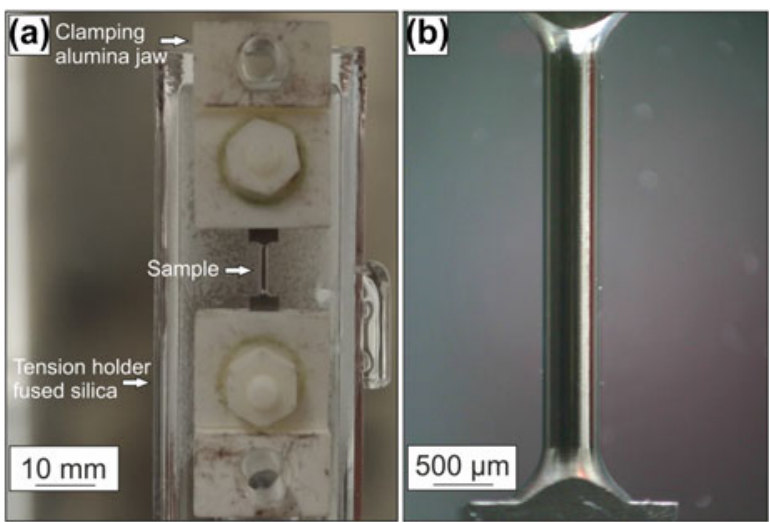

Figure 8: (a) TMA setup with fused silica tension holder, pushrod and clamping jaw made of alumina for mounting the (b) polished tensile specimen before creep testing with a diameter of $450 \pm 2 \mu \mathrm{m}$ over the entire gauge length of $2500 \mu \mathrm{m}$.

achieve thermal equilibrium of the whole setup. The TMA is a load controlled setup in which the load was increased within $1 \mathrm{~min}$ from $50 \mathrm{mN}$ to a constant load of $2.35 \mathrm{~N}$ over the whole test duration after the holding period. In respect to the sample's diameter of $450 \mu \mathrm{m}$, this led to a stress of $15 \mathrm{MPa}$ at the beginning of the tests. The sample holder and the pushrod are made of fused silica, which is thermally stable up to $1100{ }^{\circ} \mathrm{C}$. The clamping jaws with the hexagonal bolts and nuts, as well as the upper parts of the clamp with a ground cutting edge for mounting the sample, are made of alumina. The TMA setup and a microtensile specimen before testing are shown in Fig. 8.

\section{Acknowledgments}

The authors would like to acknowledge Dr. Georg Rathmayr from Microsample $\mathrm{GmbH}$ for manufacturing the microtensile specimens. The authors acknowledge funding by the Deutsche Forschungsgemeinschaft (DFG) through projects A6 and B6 of the collaborative research center SFB/TR 103 "From Atoms to Turbine Blades-a Scientific Approach for Developing the Next Generation of Single Crystal Superalloys.”

\section{References}

1. D.R. Clarke and S.R. Phillpot: Thermal barrier coating materials. Mater. Today 8, 22 (2005).

2. G.W. Goward: Progress in coatings for gas turbine airfoils. Surf. Coat. Technol. 108, 73 (1998).

3. J.R. Nicholls: Advances in coating design for high-performance gas turbines. MRS Bull. 28, 659 (2003).

4. E. Hejrani, D. Sebold, W.J. Nowak, G. Mauer, D. Naumenko, R. Vaßen, and W.J. Quadakkers: Isothermal and cyclic oxidation behavior of free standing MCrAlY coatings manufactured by high-velocity atmospheric plasma spraying. Surf. Coat. Technol. 313, 191 (2017).
5. A. Gil, V. Shemet, R. Vassen, M. Subanovic, J. Toscano, D. Naumenko, L. Singheiser, and W.J. Quadakkers: Effect of surface condition on the oxidation behaviour of MCrAlY coatings. Surf. Coat. Technol. 201, 3824 (2006).

6. D. Naumenko, R. Pillai, A. Chyrkin, and W.J. Quadakkers: Overview on recent developments of bondcoats for plasma-sprayed thermal barrier coatings. J. Therm. Spray Technol. 26, 1743 (2017).

7. R. Webler, M. Ziener, S. Neumeier, P.J. Terberger, R. Vaßen, and M. Göken: Evolution of microstructure and mechanical properties of coated Co-base superalloys during heat treatment and thermal exposure. Mater. Sci. Eng., A 628, 374 (2015).

8. M.G. Hebsur and R.V. Miner: Stress rupture and creep behavior of a low pressure plasma-sprayed NiCoCrAlY coating alloy in air and vacuum. Thin Solid Films 147, 143 (1987).

9. M. Funk, K. Ma, C. Eberl, J.M. Schönung, M. Göken, and K.J. Hemker: High-temperature mechanical behavior of end-oflife cryomilled NiCrAlY bond coat materials. Metall. Mater. Trans. A 42, 2233 (2011).

10. O. Franke, K. Durst, and M. Göken: Microstructure and local mechanical properties of Pt-modified nickel aluminides on nickelbase superalloys after thermo-mechanical fatigue. Mater. Sci. Eng., A 467, 15 (2007).

11. S. Wöllmer, S. Zaefferer, M. Göken, T. Mack, and U. Glatzel: Characterization of phases of aluminized nickel base superalloys. Surf. Coat. Technol. 167, 83 (2003).

12. K. Schneider and H.W. Grünling: Mechanical aspects of high temperature coatings. Thin Solid Films 107, 395 (1983).

13. R. Vaßen, S. Giesen, and D. Stöver: Lifetime of plasma-sprayed thermal barrier coatings: Comparison of numerical and experimental results. J. Therm. Spray Technol. 18, 835 (2009).

14. K.A. Unocic, J. Bergholz, T. Huang, D. Naumenko, B.A. Pint, R. Vaßen, and W.J. Quadakkers: High-temperature behavior of oxide dispersion strengthening CoNiCrAlY. Mater. High Temp. 35, 108 (2018).

15. C. Vorkötter, D.E. Mack, O. Guillon, and R. Vaßen: Superior cyclic life of thermal barrier coatings with advanced bond coats on single-crystal superalloys. Surf. Coat. Technol. 361, 150 (2019).

16. E. Arzt and P. Grahle: High temperature creep behavior of oxide dispersion strengthened NiAl intermetallics. Acta Mater. 46, 2717 (1998).

17. E. Arzt, R. Behr, E. Göhring, P. Grahle, and R.P. Mason:

Dispersion strengthening of intermetallics. Mater. Sci. Eng., A 234, 22 (1997).

18. P. Grahle and E. Arzt: Microstructural development in dispersion strengthened NiAl produced by mechanical alloying and secondary recrystallization. Acta Mater. 45, 201 (1997).

19. U.E. Klotz, R.P. Mason, E. Göhring, and E. Arzt: Hightemperature creep in a coarse-grained oxide-dispersion strengthened $\mathrm{Ni}_{3} \mathrm{Al}$ alloy. Mater. Sci. Eng., A 231, 198 (1997). 
20. R. Behr, J. Mayer, and E. Arzt: TEM investigations of the superdislocations and their interaction with particles in dispersion strengthened intermetallics. Intermetallics 7, 423 (1999).

21. Z. Alam, D. Eastman, M. Jo, and K. Hemker: Development of a high-temperature tensile tester for micromechanical characterization of materials supporting meso-scale ICME models. JOM 68, 2754 (2016).

22. K.J. Hemker, B.G. Mendis, and C. Eberl: Characterizing the microstructure and mechanical behavior of a two-phase $\mathrm{NiCoCrAlY}$ bond coat for thermal barrier systems. Mater. Sci. Eng., A 483-484, 727 (2008).

23. N.B. Jaya and M.Z. Alam: Small-scale mechanical testing of materials. Curr. Sci. 105, 1073 (2013).

24. L. Luan, H. Riesch-Oppermann, and M. Heilmaier: Tensile creep of miniaturized specimens. J. Mater. Res. 32, 4563-4572(2017).

25. K. Kumar, A. Pooleery, K. Madhusoodanan, R.N. Singh, J.K. Chakravartty, B.K. Dutta, and R.K. Sinha: Use of miniature tensile specimen for measurement of mechanical properties. Procedia Eng. 86, 899 (2014).

26. K. Kumar, A. Pooleery, K. Madhusoodanan, R.N. Singh, A. Chatterjee, B.K. Dutta, and R.K. Sinha: Optimisation of thickness of miniature tensile specimens for evaluation of mechanical properties. Mater. Sci. Eng., A 675, 32 (2016).

27. G.B. Rathmayr, A. Bachmaier, and R. Pippan: Development of a new testing procedure for performing tensile tests on specimens with sub-millimetre dimensions. J. Test. Eval. 41, 20120175 (2013).

28. H. Chen: Microstructure characterisation of un-melted particles in a plasma sprayed CoNiCrAlY coating. Mater. Charact. 136, 444 (2018).

29. H. Chen, Y.Q. Si, and D.G. McCartney: An analytical approach to the $\beta$-phase coarsening behaviour in a thermally sprayed CoNiCrAlY bond coat alloy. J. Alloys Compd. 704, 359 (2017).
30. S.V. Raj: Tensile creep of polycrystalline near-stoichiometric NiAl. Mater. Sci. Eng., A 356, 283 (2003).

31. S. Karashima, H. Oikawa, and T. Motomiya: Steady-state creep characteristics of polycrystalline nickel in the temperature range 500 to $1000{ }^{\circ} \mathrm{C}$. Trans. Jpn. Inst. Met. 10, 205 (1969).

32. S.V. Raj: Tensile creep fracture of polycrystalline nearstoichiometric NiAl. Mater. Sci. Eng., A 381, 154 (2004).

33. H. ur Rehman, K. Durst, S. Neumeier, A. Sato, R. Reed, and M. Göken: On the temperature dependent strengthening of nickel by transition metal solutes. Acta Mater. 137, 54 (2017).

34. M.G. Hebsur and R.V. Miner: High temperature tensile and creep behaviour of low pressure plasma-sprayed $\mathrm{Ni}-\mathrm{Co}-\mathrm{Cr}-\mathrm{Al}-\mathrm{Y}$ coating alloy. Mater. Sci. Eng. 83, 239 (1986).

35. E. Arzt and D.S. Wilkinson: Threshold stresses for dislocation climb over hard particles: The effect of an attractive interaction. Acta Metall. 34, 1893 (1986).

36. J. Bergholz, B.A. Pint, K.A. Unocic, and R. Vaßen: Fabrication of oxide dispersion strengthened bond coats with low $\mathrm{Al}_{2} \mathrm{O}_{3}$ content. J. Therm. Spray Technol. 26, 868 (2017).

37. S. Kumar, R. Singh, T.P. Singh, and B.L. Sethi: Surface modification by electrical discharge machining: A review. J. Mater. Process. Technol. 209, 3675 (2009).

38. L.C. Lee, L.C. Lim, V. Narayanan, and V.C. Venkatesh: Quantification of surface damage of tool steels after EDM. Int. J. Mach. Tool Manuf. 28, 359 (1988).

39. G.B. Rathmayr, A. Hohenwarter, and R. Pippan: Influence of grain shape and orientation on the mechanical properties of high pressure torsion deformed nickel. Mater. Sci. Eng., A 560, 224 (2013). 